\title{
Determinants of Corporate Hedging Activities with Financial Distress as a Moderating Variable
}

\author{
Ninuk Dewi Kesumaningrum ${ }^{1}$, Raden Weddie Andriyanto ${ }^{2}$ \\ \{ninukdewi@gmail.com ${ }^{1}$, r_weddie@yahoo.com ${ }^{2}$ \} \\ University of Lampung ${ }^{1}$, University of Lampung ${ }^{2}$
}

\begin{abstract}
This study aims to explore determinant variables of corporate hedging activities with financial distress as a moderating variable based on Agency Theory. Determinant variables tested were leverage, institutional ownership, company size, and company growth opportunity. Several companies in Indonesia have carried out hedging activities to protect operational and financial risks resulting from international trade. Sampling used with a purposive sampling technique and selected 165 companies from all companies listed on the Indonesia Stock Exchange in 2012-2018. This study found that leverage, institutional ownership, company size, and company growth opportunity significantly affect corporate hedging activities. Moreover, financial distress strengthens the effect of the independent variables on the dependent variable.
\end{abstract}

Keywords: Leverage, Institutional Ownership, Company Size, Company Growth Opportunity, Financial Distress, Hedging, Agency Theory

\section{Introduction}

National and multinational companies can operate within one country and work across national borders, affecting the cash inflows and cash outflows of companies from international trade between various countries. This global trade activity is carried out to meet countries' needs in goods and services. Companies carry out import activities from other countries and export activities to other countries to increase their business. Until now, the development of the Indonesian economy has not shown stability so that it can trigger companies to decide to seek funding/debt from abroad for their companies going concerned [1].

Export-import activities require companies to use foreign currency to sell and purchase their products; this causes the company to suffer the risk of foreign exchange exposure due to fluctuations in the exchange rate of domestic currency against foreign currency values in the future [2]. The compan's type of risk can be identified by first measuring the company's exposure. The most common directions have to do with financial measures, such as stock prices, profits, and sales growth [3]. The risk of loss in foreign currency exchange can affect economic activities, such as sales, changes in product prices, and asset value. The risk of loss in currency exchange rates can also affect the company's cash inflows. When the domestic currency depreciates, the import costs and the amount of foreign debt will increase, which is detrimental to the company. After all, the costs incurred will increase in number and reduce the profit obtained [2].

Risk management must overcome or reduce the financial risk that exists, especially the risk of loss in foreign currency exchange. Companies can carry out a policy, namely hedging. 
Hedging is the act of protecting the value of assets or debts held against possible risks due to a decrease in asset value or an increase in debt through the use of derivative instruments such as forward contracts, swaps, futures, or options [4]. Hedging is a derivative instrument used to stem or cover losses due to the negative impact of changes in interest rates, foreign exchange rates, and commodity prices [5]. Companies' hedging strategy for their financial transactions and derivative instruments is one of the alternatives in the capital market that has a significant role. Derivatives are contracts between two parties to buy or sell goods (financial assets or commodities) on an agreed date in the future at a price that has been decided at this time [6]. The use of hedging policies with derivative instruments has increased in recent years in developed countries. However, empirical studies on the determinants of hedging policies are still limited and require extensive research, especially in developing countries [7].

Another internal factor that influences a company to conduct hedging activities is financial distress. Financial distress is a stage of decreasing a company's financial condition before bankruptcy or liquidation [8]. A company that has an indication of bankruptcy from financial distress calculations will encourage management to protect the company from various risks, including market risk, by engaging in hedging activities [9]. This study aims to examine leverage, institutional ownership, company size, and company growth opportunities for hedging activities, with financial distress as a moderating variable.

\section{Literature Review}

Agency theory assumes that each individual is solely motivated by his interests, giving rise to a conflict of interest between the principal and agent [10]. The principal is encouraged to enter into a contract for the welfare of himself with increasing profitability. Agents are motivated to maximize the fulfillment of their economic and psychological needs, including in obtaining investment, loans, and compensation contracts.

Conflicts of interest between managers and shareholders can be minimized through a supervisory mechanism that can align these interests. However, the emergence of this supervisory mechanism will create agency costs. Where institutional ownership acts in the same way as principals who both dislike the opportunistic behavior of managers, the higher the institutional ownership in a company causes the greater the level of supervision and monitoring of managers, thereby reducing the opportunistic behavior of managers such as hedging activities [2]. However, the higher the DER value, the greater the company's risk of default [11]. This high ratio shows that the total debt composition is greater than the entire equity itself so that managers tend to hedge to overcome and reduce the risk of currency exchange losses.

This paper discusses the determinants of hedging activities with financial distress as a moderating variable based on Agency Theory. The determinants tested were leverage, institutional ownership, company size, and company growth opportunity. Some previous studies showed that leverage [1], [12], [13], institutional ownership [2], [14], [15], company size [2], [3], [16] and company growth opportunity [1], [16], [17] affect corporate hedging activities. Furthermore, firms introduce hedging to lower expected costs of financial distress [18]. This study explores that the effect of determinant variables on corporate hedging activities will be strengthened by financial distress.

Leverage is a ratio that shows the balance between debt and equity in company funding and shows the company's own capital ability to meet all its obligations. High leverage 
indicates that the company's dependence on debt is much higher than shareholder equity. Hedging must be implemented to minimize the higher risk. [11] stated that the greater the leverage, the higher the company's risk of default. If such conditions occur, then the action that must be taken is to implement a hedging policy to minimize the risk; otherwise, it will cause the risk of bankruptcy, with a higher risk [1]. So the higher the leverage, the more companies will do hedging activities. This result is also stated by the previous research conducted by [12] and [13].

$\mathrm{H}_{1}$ : Leverage has a positive effect on hedging activity

Institutional ownership is the ratio between the institution's total shares and the company's total shares. This ratio describes how much shares are owned by an institution or an institution in the company. The more investment value that is given to an organization, the higher the organization's monitoring system. Companies with greater institutional ownership tend not to engage in hedging activities [14] because hedging activities require more costs, affecting company earnings and reducing the return rate received by shareholders [2]. [15] and [14] found that institutional ownership has a negative effect on hedging activity.

$\mathrm{H}_{2}$ : Institutional ownership has a negative effect on hedging activity

The size of a company makes different decisions. The bigger the company, the higher the risks that will occur. Large companies will do better risk management in their companies than small companies [3], so that the bigger the company will tend to use hedging activities to protect the assets that exist in the company because the more significant the risk company faced will also be greater [2] and [16].

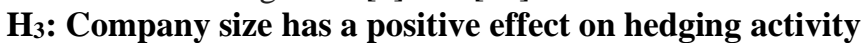

One way to get funding sources quickly to finance a company's growth is to include references of debt into the company's capital structure [3]. [17] revealed that companies with high growth rates need more funding to invest in developing the company because they cannot finance investment with internal funds. The company undertakes external financing in foreign currency. External funding with foreign currency can potentially be exposed to the risk of increasing total debt and default due to exchange rate fluctuations [2]. The tremendous growth opportunity has the opportunity for companies to experience underinvestment problems. Underinvestment problems arise when a company cannot fund a particular investment due to external factors that can affect its internal cash flow [17]. The result of research conducted by [1], [16], [15], and [2] provides that the company growth opportunity has a positive effect on hedging activity.

\section{$\mathrm{H}_{4}$ : Growth opportunity has a positive effect on hedging activity}

Corporate hedging activities have several factors that influence it, such as liquidity, leverage, company size, firm value, and company growth opportunities. Prior studies identify specific benefits that induce firms to hedge. One of the advantages is the reduction of expected costs of financial distress. [19] and [20] indicate that a reduction in the variability of cash flows and firm value reduces financial distress's expected costs. Some of the typical costs arise from deterioration of long-term relationships with suppliers and customers during financial distress periods. Consequently, firms with high financial distress should have more significant incentives to hedge their risks [18].

H$_{5}$ : Financial distress can strengthen the positive effect of leverage on hedging activity

$H_{6}$ : Financial distress can strengthen the negative effect of institutional ownership on hedging activity

$\mathrm{H}_{7}$ : Financial distress can strengthen the positive effect of company size on hedging activity 
H8: Financial distress can strengthen the positive effect of growth opportunity on
hedging activity

\section{Methodology and Data Analysis}

Secondary data were collected using the documentation technique used as data in this study. All companies listed on the Indonesia Stock Exchange in 2012-2018 were used in the study. From the purposive sampling technique, 165 companies with 1155 observed items were selected to be the sample. Inferential statistical analysis used logistic regression and complete difference test value analysis for moderating variables.

Table 1. Variable Definition and Measurement

\begin{tabular}{|l|l|l|}
\hline \multicolumn{1}{|c|}{ Variables } & \multicolumn{1}{|c|}{ Operational Definition } & \multicolumn{1}{c|}{ Measurement } \\
\hline Hedging Activity & $\begin{array}{l}\text { the act of protecting the value of assets or debts } \\
\text { held against possible risks due to a decrease in } \\
\text { asset value or an increase in debt through the use } \\
\text { of derivative instruments [5] }\end{array}$ & $\begin{array}{l}\text { Score 1 = do the act } \\
\text { Score 0= not do the act } \\
{[12]}\end{array}$ \\
\hline Leverage & $\begin{array}{l}\text { a ratio that shows the balance between debt and } \\
\text { equity in company funding and shows the } \\
\text { company's own capital ability to meet all its } \\
\text { obligations [11] }\end{array}$ & DER [11] \\
\hline $\begin{array}{l}\text { Institutional } \\
\text { Ownership }\end{array}$ & $\begin{array}{l}\text { the ratio between the total shares of the institution } \\
\text { and the total shares owned by the company }\end{array}$ & {$[14]$} \\
\hline Company Size & Total assets & {$[3]$} \\
\hline Growth Opportunity & $\begin{array}{l}\text { a ratio that measures the opportunities or } \\
\text { opportunities of his business in the future }\end{array}$ & {$[21]$} \\
\hline Financial Distress & $\begin{array}{l}\text { Circumstances before bankruptcy or liquidation } \\
\text { where financial conditions decline [8] }\end{array}$ & $\begin{array}{l}\text { Score 1 for ICR <1.00, } \\
\text { score } \\
0 \text { for ICR> 1.00 } \\
{[22]}\end{array}$ \\
\hline
\end{tabular}

\section{$4 \quad$ Research Result and Discussion}

Based on the test results, all the classical assumption tests (normality test, heteroscedasticity, multicollinearity, and autocorrelation) can be fulfilled. That is, the data used in this study have met the requirements of the classical assumptions.

Table 2. Result

\begin{tabular}{|c|l|c|c|l|}
\hline No & \multicolumn{1}{|c|}{ Hypothesis } & B & Sig. & \multicolumn{1}{|c|}{ Result } \\
\hline 1 & Leverage has a positive effect on hedging activity & 1.718 & 0.000 & Accepted \\
\hline 2 & $\begin{array}{l}\text { Institutional Ownership has a negative effect on hedging } \\
\text { activity }\end{array}$ & -0.323 & 0.039 & Accepted \\
\hline 3 & Company Size has a positive effect on hedging activity & 1.237 & 0.027 & Accepted \\
\hline 4 & $\begin{array}{l}\text { Growth Opportunity has a positive effect on hedging } \\
\text { activity }\end{array}$ & 0.383 & 0.019 & Accepted \\
\hline 5 & Financial distress can strengthen the positive effect of & 0.246 & 0.009 & Accepted \\
\hline
\end{tabular}




\begin{tabular}{|c|l|c|c|l|}
\hline & leverage on hedging activity & & & \\
\hline 6 & $\begin{array}{l}\text { Financial distress can strengthen the negative effect of } \\
\text { institutional ownership on hedging activity }\end{array}$ & -0.944 & 0.000 & Accepted \\
\hline 7 & $\begin{array}{l}\text { Financial distress can strengthen the positive effect of } \\
\text { company size on hedging activity }\end{array}$ & 0.130 & 0.003 & Accepted \\
\hline 8 & $\begin{array}{l}\text { Financial distress can strengthen the positive effect of } \\
\text { growth opportunity on hedging activity }\end{array}$ & 0.039 & 0.014 & Accepted \\
\hline
\end{tabular}

Source: Secondary Data Processed by SPSS

Based on the results above, this study found that leverage, company size, and growth opportunity positively affect corporate hedging activities. The company will minimize the risk of default on its debt by implementing hedging activities. This result is in line with the findings by [1], [12], and [13]. The company with large total assets will do more risk management like hedging activity; this is also stated in research conducted by [2], [16], and [3]. The results revealed that companies with high growth rates need more funding to invest in developing companies because they cannot finance investment with internal funds. The company carries out external financing in foreign currency, which further encourages companies to carry out hedging activities [17]. This study also showed that institutional ownership has a negative effect on hedging activity, and this is in accordance with research conducted by [15] and [14] which provided evidence that companies with higher institutional ownership tend not to engage in hedging activities. Besides, the result provided evidence that financial distress as a moderating variable can strengthen the effect of determinant variables on hedging activity.

\section{Conclusion}

Hedging is an activity to protect the company from avoiding or reducing the risk of loss on foreign currency due to the company's business transactions and according to [5], hedging as a derivative instrument used to stem or offset the adverse effects of changes in interest rates, foreign exchange rates, and commodity prices. Derivative instruments, namely options, forward or futures contracts, and swaps perform hedging activities. Based on this study and previous studies results, it was concluded that leverage, institutional ownership, company size, and company growth opportunity significantly affect corporate hedging activities. Moreover, the effects of determinant variables were strengthened by financial distress as moderating variables.

Acknowledgments. The authors would like to thank University of Lampung for financial support of this study by a DIPA BLU research grant.

\section{References}

[1] D. P. Kurniawan and N. Asandimitra, "Analisis Faktor Yang Mempengaruhi Penggunaan Instrumen Derivatif Sebagai Pengambilan Keputusan Hedging Pada Perusahaan Sektor Keuangan Yang Terdaftar Di Bei Periode 2011-2015," J. Ilmu 
Manaj., vol. 6, no. 1, pp. 1-11, 2018.

[2] N. Hidayah and Prasetiono, "Faktor Penentu Perusahaan Melakukan Pengambilan Keputusan Hedging pada Derivatif Valuta Asing," Diponegoro J. Manag., 2016, doi: 10.1080/09523367.2014.915518.

[3] S. H. Putro and M. Chabachib, "Analisis Faktor yang Mempengaruhi Penggunaan Instrumen Derivatif Sebagai Pengambilan Keputusan Hedging," Diponogoro Bus. Rev., 2012.

[4] M. Samsul, Pasar Berjangka Komoditas dan Derivatif. Jakarta : Salemba Empat, 2010.

[5] D. E. Kieso, J. J. Weygandt, and T. Warfield, Akuntansi Intermediate. Jakarta: Jakarta : Erlangga, 2008.

[6] L. L. Utomo, "Instrumen Derivatif: Pengenalan Dalam Strategi Manajemen Risiko Perusahaan,” J. Akunt. dan Keuang., vol. 2, no. 1, pp. 53-68, 2000, doi: 10.9744/jak.2.1.pp.53-68.

[7] K. Ben Khediri and D. Folus, "Does hedging increase firm value? Evidence from French firms," Appl. Econ. Lett., vol. 17, no. 10, pp. 995-998, 2010, doi: 10.1080/17446540802599697.

[8] H. D. Platt and M. B. Platt, "A note on the use of industry-relative ratios in bankruptcy prediction,” J. Bank. Financ., vol. 15, no. 6, pp. 1183-1194, 1991, doi: 10.1016/03784266(91)90057-S.

[9] I. Aslikan and S. Rokhmi, "Faktor-faktor yang mempengaruhi Keputusan Hedging pada Perusahaan Manufaktur," J. Ilmu dan Ris. Manaj., 2017.

[10] M. C. Jensen and W. H. Meckling, "Theory of the firm: Managerial behavior, agency costs and ownership structure," J. financ. econ., 1976, doi: 10.1016/0304405X(76)90026-X.

[11] Kasmir, Analisis Laporan Keuangan. Jakarta : PT. Raja Grafindo Persada, 2012.

[12] E. S. Paranita, "Kebijakan Hedging Dengan Derivatif Valuta Asing Pada Perusahaan Publik Di Indonesia,” Semin. Nas. Ilmu Ekon. Terap., no. 32, pp. 228-237, 2011.

[13] V. W. Tai, Y. H. Lai, and L. Lin, "Local institutional shareholders and corporate hedging policies," North Am. J. Econ. Financ., vol. 28, no. 1, pp. 287-312, 2014, doi: 10.1016/j.najef.2014.03.009.

[14] X. Wang and L. Fan, "The Determinants of Corporate Hedging Policies," Int. J. Bus. Soc. Sci., vol. 2, no. 6, pp. 29-38, 2011, [Online]. Available: http://www.ijbssnet.com/journals/Vol._2_No._6\%3B_April_2011/4.pdf.

[15] R. Ameer, F. Ramli, and H. Zakaria, "A new perspective on board composition and firm performance in an emerging market," Corp. Gov., vol. 10, no. 5, pp. 647-661, 2010, doi: 10.1108/14720701011085607.

[16] M. J. W. A. Kussulistyanti and Mahfudz, “Analisis Faktor-Faktor Yang Memengaruhi Keputusan Hedging Dengan Derivatif Valuta Asing (Studi Pada Perusahaan NonFinansial yang Terdaftar Di Bursa Efek Indonesia Periode Tahun 2011-2014)," Diponegoro J. Manag., vol. 5, no. 3, pp. 1-14, 2016, [Online]. Available: http://ejournal-s1.undip.ac.id/index.php/management.

[17] R. R. Repie and I. B. P. Sedana, "Kebijakan Hedging dengan Instrumen Derivatif dalam Kaitan dengan Underinvestment Problem di Indonesia," J. Ekon. dan Bisnis, pp. 384-398, 2014.

[18] Z. Iqbal, "Financial distress around introduction of hedging in the oil and gas industry," Int. J. Bus., vol. 20, no. 1, pp. 79-89, 2015.

[19] D. Mayers and C. W. Smith, Jr., "On the Corporate Demand for Insurance," J. Bus., 
vol. 55, no. 2, p. 281, 1982, doi: 10.1086/296165.

[20] C. W. Smith and R. M. Stulz, "This content downloaded from 66.176.208.112 on Mon," PM All use Subj. to JSTOR Terms Cond. J. Financ. Quant. Anal., vol. 20, no. 4, p. 36, 1985.

[21] C. W. Smith and R. L. Watts, "The investment opportunity set and corporate financing, dividend, and compensation policies," J. financ. econ., vol. 32, no. 3, pp. 263-292, 1992, doi: 10.1016/0304-405X(92)90029-W.

[22] R. Yudiawati and A. Indriani, “Analisis Pengaruh Current Ratio, Debt To Total Asset Ratio, Total Asset Turnover, dan Sales Growth Ratio Terhadap Kondisi Financial Distress Pada Perusahaan Manufaktur," Diponegoro J. Manag., vol. 5, no. 2, pp. 1-13, 2016. 